\title{
Spatio-temporal variations in seasonal ice tongue submarine melt rate at a tidewater glacier in southwest Greenland
}

\author{
A. N. MOYER, ${ }^{1}$ (1) P. W. NIENOW, ${ }^{1}$ N. GOURMELEN, ${ }^{1,2}$ A. J. SOLE, ${ }^{3}$ (ㅇ D. A. SLATER, ${ }^{4}$ \\ M. TRUFFER, ${ }^{5}$ (1) M. FAHNESTOCK ${ }^{5}$ \\ ${ }^{1}$ School of GeoSciences, University of Edinburgh, Edinburgh, UK \\ 2IPGS UMR 7516, Université de Strasbourg \\ ${ }^{3}$ Department of Geography, University of Sheffield, UK \\ ${ }^{4}$ Scripps Institution of Oceanography, University of California San Diego, La Jolla, CA, USA \\ ${ }^{5}$ Geophysical Institute, University of Alaska Fairbanks, Fairbanks, AK, USA \\ Correspondence: Alexis Moyer <a.moyer@ed.ac.uk>
}

\begin{abstract}
Submarine melting of tidewater glaciers is proposed as a trigger for their recent thinning, acceleration and retreat. We estimate spring submarine melt rates (SMRs) of Kangiata Nunaata Sermia in southwest Greenland, from 2012 to 2014, by examining changes in along-fjord freeboard and velocity of the seasonal floating ice tongue. Estimated SMRs vary spatially and temporally near the grounding line, with mean rates of $1.3 \pm 0.6,0.8 \pm 0.3$ and $1.0 \pm 0.4 \mathrm{~m} \mathrm{~d}^{-1}$ across the tongue in 2012, 2013 and 2014, respectively. Higher melt rates correspond with locations of emerging subglacial plumes and terminus calving activity observed during the melt season using time-lapse camera imagery. Modelling of subglacial flow paths suggests a dynamic system capable of rapid re-routing of subglacial discharge both within and between melt seasons. Our results provide an empirically-derived link between the presence of subglacial discharge plumes and areas of high spring submarine melting and calving along glacier termini.
\end{abstract}

KEYWORDS: glacier calving, ice/ocean interactions, remote sensing, subglacial processes

\section{INTRODUCTION}

In recent decades, decreases in surface mass balance (SMB) and increases in ice discharge from tidewater glaciers into the ocean have accelerated ice loss from the Greenland Ice Sheet (van den Broeke and others, 2016). Despite the inferred connection between oceanic warming and increased ice discharge (e.g., Holland and others, 2008; Straneo and Heimbach, 2013), our understanding of ice/ocean interactions at the margins of the ice sheet remains limited. In particular, submarine melting of glacier termini is poorly understood, with few observational estimates of melt rates due to the difficulty of collecting in-situ data near actively calving glacial termini. Submarine melting has been proposed as a trigger for glacier calving, retreat and acceleration (O'Leary and Christoffersen, 2013; Luckman and others, 2015), and is thought to influence ice front morphology by undercutting termini and creating embayments through enhanced calving rates (Carroll and others, 2015; Fried and others, 2015; Slater and others, 2017a).

To date, many studies have used numerical models, observations and laboratory experiments to show that submarine melting is amplified where subglacial discharge plumes emerge at the glacier grounding line (e.g., Jenkins, 2011; Motyka and others, 2013; Slater and others, 2015; Cenedese and Gatto, 2016). Due to the lower density of subglacial discharge relative to the ambient fjord water, such plumes rise buoyantly along the ice front, entraining warmer fjord waters and melting the ice front and underside of any ice tongue present (e.g., Motyka and others, 2003;
Jenkins, 2011, Moyer and others, 2017). Submarine melt rates (SMRs) are understood to be a function of the water temperature and velocity of the rising subglacial plume (Jenkins, 2011), factors which are themselves influenced by the ambient fjord temperature, stratification and the volume and distribution of the emerging subglacial meltwater (e.g., Carroll and others, 2015; Slater and others, 2015).

Here, we connect variations in floating ice tongue spring SMRs with the presence and location of summer subglacial meltwater plumes and of locally enhanced calving from 2012 to 2014 at Kangiata Nunaata Sermia (KNS), southwest Greenland.

\section{STUDY SITE}

Our study is focused on KNS, the largest tidewater glacier in southwest Greenland, which drains into Kangersuneq Fjord at the head of the extensive Godthåbsfjord system (Fig. 1). The glacier front is $4.5 \mathrm{~km}$ wide and has a maximum grounding line depth of $\sim 250 \mathrm{~m}$ below sea level (Mortensen and others, 2013). In common with many Greenlandic tidewater glaciers, KNS forms a floating ice tongue over the winter, which extends $2-3 \mathrm{~km}$ from the glacier grounding line and decreases in freeboard with distance down-fjord (Figs 1d and 2a; Moyer and others, 2017). Analyses of fjord water properties show that Kangersuneq Fjord is stratified with relatively warm subsurface waters (up to $2.5^{\circ} \mathrm{C}$ ) overlain by cooler water masses (between 0 and $1^{\circ} \mathrm{C}$ ) (Mortensen and others, 2013; Motyka and others, 2017). 

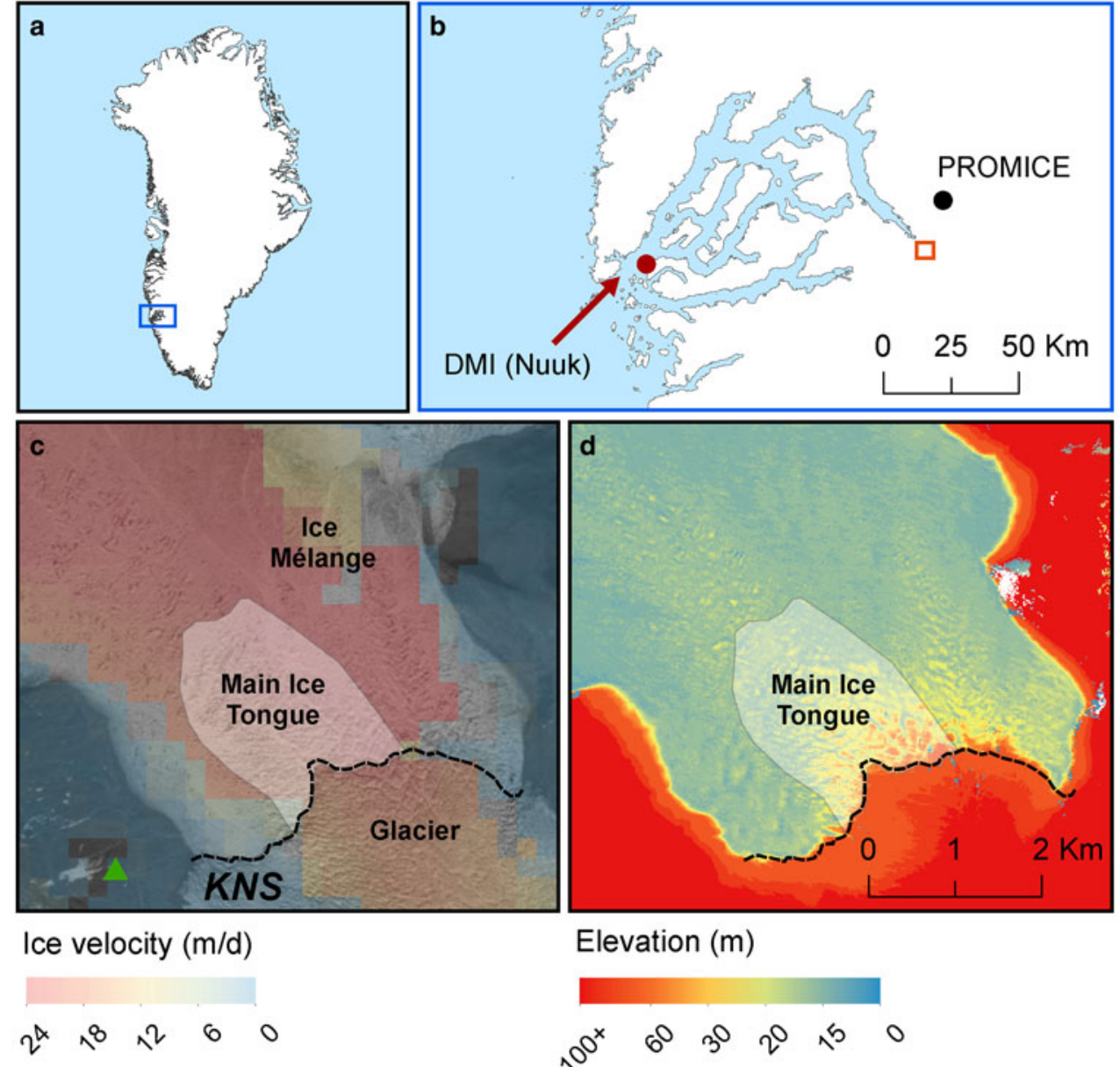

Elevation $(m)$

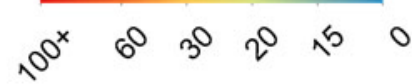

Fig. 1. Study area, including (a) Greenland location map where blue rectangle indicates the extent of (b); (b) fjord-scale location map within the wider Godthåbsfjord system with location of two weather stations: Danish Meteorological Institute (DMI) Nuuk (red filled circle) and PROMICE NUK_L (black filled circle). The open orange square corresponds to the location of (c, d); (c) a Landsat 8 band 8 satellite image of the KNS glacier ice tongue, acquired on 27 May 2014. The black dashed line indicates the estimated grounding line position (handdigitized using both a Landsat 8 image from 12 June 2014 and the TanDEM-X DEM from 5 June 2014), the green triangle indicates the location of the University of Alaska Fairbanks time-lapse camera and the semi-transparent white polygon indicates the main ice tongue extent. Ice velocity from 27 May to 12 June is overlain, derived from the feature tracking of Landsat 8 imagery (Rosenau and others, 2015); and (d) sample TanDEM-X derived elevation for KNS ice tongue, glacier and surrounding bedrock areas from 14 May 2014.

\section{DATA AND METHODOLOGY}

\subsection{Elevation and ice velocity data}

Five $2.5 \mathrm{~m}$ resolution digital elevation models (DEMs) of the study area were generated from conventional SAR interferometric processing of bi-static TanDEM-X imagery (Dehecq and others, 2016), as detailed in Moyer and others (2017). DEMs were acquired for the following dates: 13 May 2012, 17 March 2013, 27 May 2013, 14 May 2014 and 5 June 2014. We used both ICESat and Operation IceBridge (OIB) Airborne Topographic Mapper (ATM) elevation data (Krabill, 2016) to perform co-registration and corrections to our derived DEMs. ICESat elevations were used for calibration over non-ice-covered terrain and OIB ATM elevations were used to correct a tilt in the data over the ice-covered fjord (Moyer and others, 2017) (Fig. S1). This tilt, $\sim 0.45 \mathrm{~m} \mathrm{~km}^{-1}$ down-fjord, was introduced during DEM co-registration due to the limited coverage of the ICESat lines over stable bedrock regions. OIB ATM data from 25 April 2012 and 15 April 2014 were used to correct our 2012 and 2014 DEMs, respectively. As there was no OIB campaign over our study area in 2013, we corrected our 2013 DEMs using OIB ATM data from 8 April 2011, chosen due to similar fjord sea-ice cover in both years (Fig. S2), likely due to comparable innerfjord water (Motyka and others, 2017) and air temperatures.

Three $20 \mathrm{~m}$ horizontal resolution ice velocity maps were generated using conventional feature tracking of spring 2013 TerraSAR-X imagery (e.g., Paul and others, 2015), and acquired from the following image pairs (to correspond with our 17 March and 27 May 2013 DEMs): 12 and 23 February; 8 and 19 April; 30 April and 11 May (see Moyer and others (2017) for more details). For 2012 and 2014, we use velocity maps generated from combined feature tracking of Landsat 7 and 8 imagery (Rosenau and others, 2015) for the following image pairs: 6 and 22 May 2012 (to correspond with our 13 May 2012 DEM) and 27 May and 12 June 2014 (to correspond with both our 14 May and 5 June 2014 DEMs). These velocities are freely available from the Technische Universität Dresden's Geodetic Data Portal (https://data1. geo.tu-dresden.de/flow_velocity/). All velocity maps can be seen in Fig. S3.

\subsection{Ice tongue surface and SMRs}

To assess potential elevation changes driven by SMB, ice tongue surface melt rates were estimated using a simple 
positive degree-day approach (Hock, 2003), details of which can be found in the Supplementary materials and Moyer and others (2017). Degree-day modelling was also used to estimate catchment-wide runoff from surface melting during the melt season at elevations below 2000 m, above which most meltwater refreezes within the snow pack (e.g., Pfeffer and others, 1991; Langen and others, 2015, 2017). Daily air temperatures were acquired from a Geological Survey of Denmark and Greenland PROMICE weather station located $\sim 21 \mathrm{~km} \mathrm{NE}$ from the KNS terminus (Ahlstrom and others, 2008) (Fig. 1b). Daily precipitation data were acquired from the Danish Meteorological Society (DMI) weather station in Nuuk, $105 \mathrm{~km}$ west of the KNS terminus (Cappelen, 2016) (Fig. 1b). The ArcticDEM (Morin and others, 2016), sampled to $90 \mathrm{~m}$ horizontal resolution, was used to estimate KNS catchment-wide runoff.

Ice tongue SMRs were estimated by differencing alongfjord flowline surface elevation in combination with ice velocities, following the methodologies in Moyer and others (2017). Flowlines were created every $25 \mathrm{~m}$ along the KNS ice tongue, starting $150 \mathrm{~m}$ from the grounding line (in order to exclude noise in velocity data as the ice moves across the grounding line) and extending $\sim 2 \mathrm{~km}$ down-fjord (see Fig. 3). To accommodate temporal changes in ice velocity, separate flowlines were created for each DEM date, resulting in a different ice tongue shape each year. Elevations along each flowline were smoothed using a two-sided moving average with a $625 \mathrm{~m}$ window, which was the smallest smoothing window that significantly reduced the effect of large crevasses on the ice elevation gradient, and then converted to thickness values assuming ice tongue floatation and hydrostatic equilibrium. Noise in velocity data along each flowline was reduced by using a linear regression of ice tongue velocity against distance down-fjord.

As we only have one DEM for 2012 and for comparison purposes, we estimate steady state SMRs, assuming ice thickness at a fixed location does not change in time. SMR accounts for thinning due to stretching in both the flow direction and perpendicular to flow:

$$
S M R=-v_{x} \frac{\partial H}{\partial x}-H \frac{\partial v_{x}}{\partial x}-H \frac{\partial v_{y}}{\partial y}-S M B
$$

where $H$ is the ice thickness (m), $v_{x}$ and $v_{y}$ are the ice velocity $\left(\mathrm{m} \mathrm{d}^{-1}\right)$ in the along- and across-flowline direction, and $x$ and $y$ represent distance in the along- and across-flowline direction. We include a potential contribution from SMB, although it will later be shown that this is negligible in our case. Note that a term representing across-flow thinning, $v_{y}(\partial H / \partial y)$, does not contribute as, by definition of a flowline, $v_{y}=0$ on the flowline. To best capture the general trend in SMRs and in order to smooth out unrealistic melt rate estimates resulting from the heavily crevassed nature of the ice tongue (and thus short-length scale high amplitude variations in elevation), exponential fits were applied to estimated flowline melt rates (following Moyer and others, 2017).

\subsection{Uncertainties in SMR estimates}

Uncertainties in our SMR estimates are associated with the quality of the elevation and velocity data, the smoothing of our flowlines and our assumption of an ice tongue in steady state. We here discuss each in turn.
There are two types of errors associated with the elevation data: the absolute error in elevation (and thus thickness, $H$ ) and the error in the elevation gradient, which impacts $\partial H$ / $\partial x$ in Eqn (1). Error in the absolute measured elevation derived from the TanDEM-x data results from the DEM construction process and typically has an uncertainty of $\pm 2 \mathrm{~m}$ over areas of slope $<12^{\circ}$ (Rizzoli and others, 2012). Error in the elevation gradient results from our DEM tilt correction using OIB ATM data, and we define it as the largest difference in slope between the OIB ATM lines and the corrected TanDEM-X elevations, as estimated over $2 \mathrm{~km}$ long segments of very thin sea ice where successive OIB ATM flights show near-constant slope (Fig. S1). The resulting elevation gradient errors are $\pm 1.78 \mathrm{~m}$ (for 2012 and 2014) and $\pm 0.38 \mathrm{~m}$ (for 2013) over the $\sim 2 \mathrm{~km}$ long ice tongue.

Uncertainties in ice tongue velocity are often the result of poor image co-registration, surface changes and transformations (e.g., changes in illumination or reflectance of surface features like snow) and mismatches between similar but not corresponding features (in this case, crevasses in the ice tongue) (Paul and others, 2015; Rosenau and others, 2015). Uncertainties in Landsat-derived ice tongue velocity for 2012 and 2014 were downloaded directly from the Technische Universität Dresden's Geodetic Data Portal, with mean uncertainties in the velocity of up to \pm 1.1 and $\pm 0.23 \mathrm{~m} \mathrm{~d}^{-1}$ for 2012 and 2014, respectively. Uncertainty in our 2013 TerraSAR-X derived ice tongue velocity was estimated following Paul and others (2015), with mean uncertainties in the velocity of $\pm 0.09 \mathrm{~m} \mathrm{~d}^{-1}$.

Uncertainties in both elevation and velocity data were combined via standard error propagation techniques to calculate the preliminary error in our SMR estimates $(\triangle S M R)$, as follows:

$$
\Delta S M R=\sqrt{\left[\Delta\left(v_{x} \frac{\partial H}{\partial x}\right)\right]^{2}+\left[\Delta\left(H \frac{\partial v_{x}}{\partial x}\right)\right]^{2}+\left[\Delta\left(H \frac{\partial v_{y}}{\partial y}\right)\right]^{2}}
$$

where $\Delta\left(v_{x}(\partial H / \partial x)\right), \Delta\left(H\left(\partial v_{x} / \partial x\right)\right)$ and $\Delta\left(H\left(\partial v_{y} / \partial y\right)\right)$ are the errors associated with the first three terms on the right-hand side of Eqn (1), respectively. The first error term, $\Delta\left(v_{x}(\partial H / \partial x)\right)$, was estimated as follows (with the second and third terms estimated in a similar fashion):

$$
\Delta\left(v_{x} \frac{\partial H}{\partial x}\right)=\left|v_{x} \frac{\partial H}{\partial x}\right| \sqrt{\left(\frac{\Delta v_{x}}{v_{x}}\right)^{2}+\left(\frac{\Delta \frac{\partial H}{\partial x}}{\frac{\partial H}{\partial x}}\right)^{2}}
$$

In addition to the uncertainty in elevation and velocity data, there are other potential sources of error that must be considered and which we treat separately. Smoothing the flowline elevations also results in uncertainty in our final SMRs, which we assess using a sensitivity analysis. Varying the moving average window size by $\pm 125 \mathrm{~m}$ results in an additional SMR uncertainty of $\pm 25 \%$, which has been directly applied to the preliminary SMR errors, above.

Finally, the assumption of an ice tongue in steady state increases uncertainty in our SMR estimates. We know that the ice tongue is not in steady state between March and May 2013, as seen in thickness changes between our two 2013 DEMs, which result from a slower moving glacier. To estimate potential errors resulting from this assumption, 

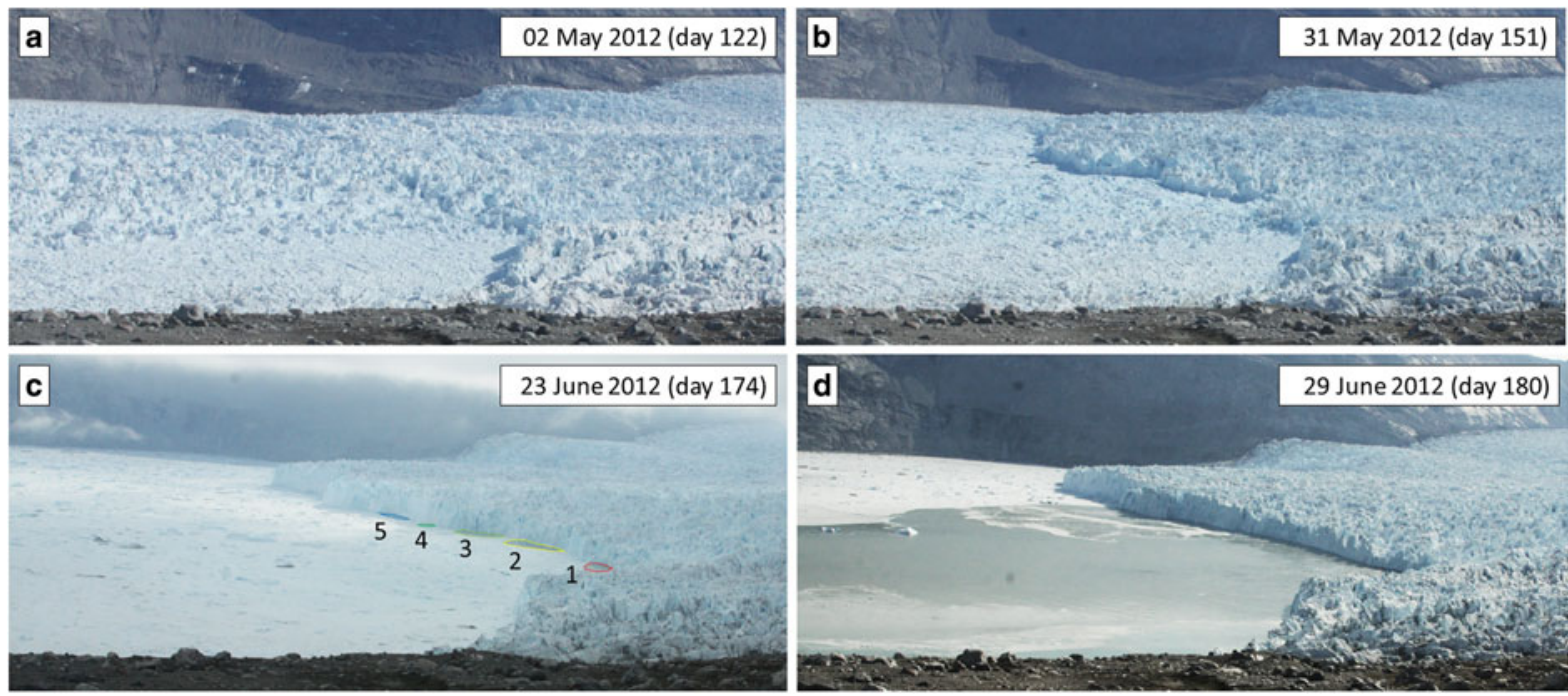

Fig. 2. Sample time-lapse images used for plume presence detection: (a) ice tongue present; (b) no plumes visible on fjord surface; (c) multiple, separate plumes visible on fjord surface, with colours and numbers used for plume location classification (see Figs 4a, b); plumes 6 and 7 (not visible here) are located east (to the left) of plume 5; and (d) a single, connected surface expression of a plume visible on fjord surface.

we estimated non-steady state SMRs for March and May 2013. We assumed a linear trend of thickening between the two DEMs (see Eqn (3) from Moyer and others (2017)), accounted for by subtracting a daily rate of thickness change from our 2013 steady state melt rate estimates. On average, ice tongue non-steady state melt rates are $0.12 \mathrm{~m} \mathrm{~d}^{-1}(23 \%)$ and $0.23 \mathrm{~m} \mathrm{~d}^{-1}(27 \%)$ lower than steady state estimates for March and May 2013, respectively (Fig. S4). These average percentage differences fall within the mean percentage differences in melt rate resulting from uncertainty in our elevation and velocity datasets (see Table S1), which range from 26 to $46 \%$. In addition, assuming an ice tongue is in steady state does not change the overall magnitude of the melt rates. As such, while the ice tongue is not in a steady state (at least for 2013), we believe that SMRs can be reasonably approximated under the assumption of an ice tongue with a steady state geometry, as we estimate here, and which is necessary for meaningful comparison to years when we only have one DEM for estimating melt rates.

\subsection{Subglacial discharge plumes, calving activity and hydrology}

To investigate the correspondence between the presence and location of subglacial discharge plumes post-ice tongue disintegration and spatial patterns in ice tongue SMRs, we created a time series of the expression of runoff plumes at the fjord surface using time-lapse imagery from a camera located on a bedrock ridge $\sim 1 \mathrm{~km}$ from the western edge of the KNS calving front (Fig. 1c). Images of the western half of the calving front were taken every 4 hours from 18 May 2012 (day 139) until 22 July 2013 (day 203). We assigned each plume a number from 1 to 7 , based on its location and moving west to east along the calving front (Fig. 2c). Plumes 6 and 7 (not pictured in Fig. 2c) occur infrequently. To avoid including open water resulting from wind or calving activity, we only identified plumes that were visibly turbid, thereby indicating a subglacial origin. In addition, while plume surface expressions are not visible at the same time as the ice tongue is intact, we assume that plume positions are the same for the period prior to the disintegration of the ice tongue.

A time series of calving activity was also created from the time-lapse images, by viewing each image for visible signs of calving and recording the time and location of each event along the calving front (either western or eastern side). Visible signs of calving include actively captured calving events, changes in fjord surface characteristics between two images (i.e., non-turbid open water adjacent to the ice front with small bergy bits), and obvious changes in ice front morphology between two images.

To assess potential spatial variations in the subglacial hydrological network below the grounded part of KNS and the predicted locations of any emerging subglacial channels along the calving front, we performed a standard hydropotential analysis with the MATLAB toolbox TopoToolBox (Shreve, 1972; Schwanghart and Scherler, 2014), using BedMachine v3 bed and surface topography (Morlighem and others, 2017) to calculate the subglacial hydraulic potential $(\phi)$ :

$$
\Phi=\rho_{\mathrm{w}} g z+f \rho_{i} g h
$$

where $\rho_{\mathrm{w}}$ and $\rho_{i}$ are the densities of meltwater $\left(1000 \mathrm{~kg} \mathrm{~m}^{-3}\right)$ and ice $\left(910 \mathrm{~kg} \mathrm{~m}^{-3}\right)$, respectively, $g$ is the acceleration due to gravity $\left(9.81 \mathrm{~m} \mathrm{~s}^{-2}\right), z$ is the bed elevation $(\mathrm{m})$, and $h$ is the ice thickness (as provided in the Bed Machine $\mathrm{v} 3$ product). $f$ is the ratio of the subglacial water pressure to the ice overburden pressure (e.g. Banwell and others, 2013), which is in general poorly known and we thus apply a range of values from $f=0.1$ to $f=1$ consistent with sparse borehole water pressure observations from Greenland (Meierbachtol and others, 2013; Andrews and others, 2014). A value $f=0.1$ means that the subglacial water pressure is a tenth of the ice overburden pressure, so that the subglacial hydrological system is at low pressure, such as might be associated with efficient subglacial drainage, while a value $f=1$ means that the subglacial water pressure is equal to the ice overburden pressure, so that the subglacial system is at high pressure, as might be associated with inefficient subglacial drainage (Fountain and Walder, 1998). 

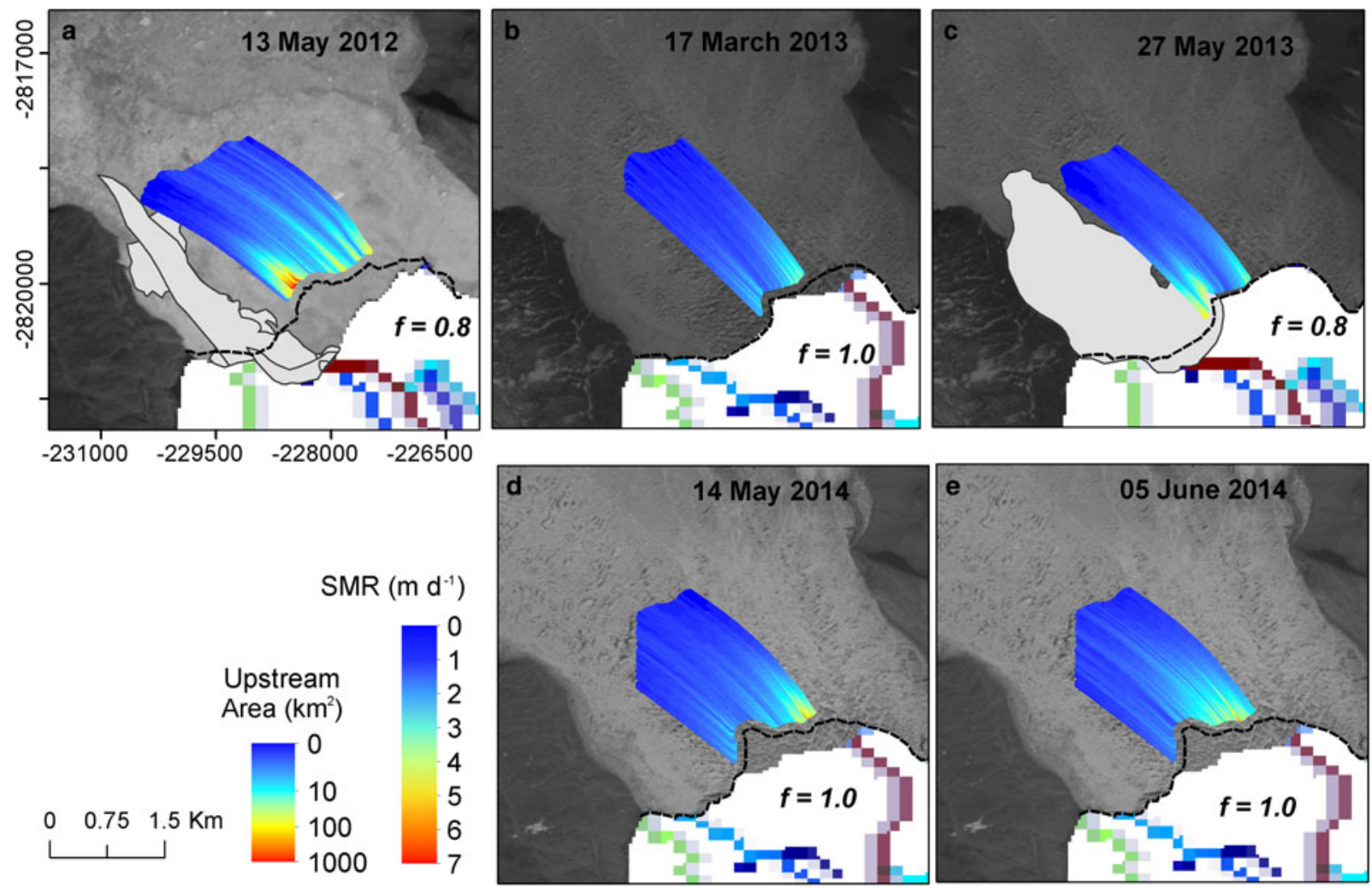

Fig. 3. Submarine melt rates (SMR) of KNS ice tongue flowlines, locations of plume surface expressions (grey polygons hand-digitized from Landsat images in Table S2), and near-terminus flow routing coloured to indicate total upstream drainage area for (a) 13 May 2012 , (b) 17 March 2013, (c) 27 May 2013, (d) 14 May 2014 and (e) 05 June 2014. Dashed black lines indicate estimated location of the grounding line in June of each year (hand-digitized from Landsat 8 imagery). Background images are all Landsat 7 and 8 , acquired for (a) 25 July 2012, (b, c) 01 May 2013 and (d, e) 12 June 2014. The chosen flow routing $f$-values (ratio of subglacial water pressure to ice overburden pressure) show the best spatial association between plume surface expressions and spatial variability in melt rate. Note that some colours seen in the flow routing are not in the colourbar (e.g., purple), as they are the result of overlapping channels (e.g., blue and red channels, but with purple being indicative of a net large upstream area).

\section{RESULTS AND DISCUSSION}

\subsection{Variations in SMRs}

Using our flowline methodology, we find that near-terminus spring SMRs for the floating ice tongue at KNS vary both temporally and spatially (Figs 3 and Fig. S5; Table S1), with mean melt rates taken over the full extent of the ice tongue ranging from $0.8 \pm 0.3 \mathrm{~m} \mathrm{~d}^{-1}$ in March and May 2013 to $1.3 \pm 0.6 \mathrm{~m}$ $\mathrm{d}^{-1}$ in May 2012. Maximum melt rates occur under the western half of the ice tongue in May 2012, reaching over $7 \mathrm{~m} \mathrm{~d}^{-1} \sim 150 \mathrm{~m}$ down-fjord from the KNS grounding line. Surface melt rates, estimated using a positive degree-day model, are at least one order of magnitude lower than our mean SMRs (Table S1), and are thus considered negligible (see Supplementary materials for more details).

Our melt rates agree well with those previously estimated in the Godthåbsfjord system. Estimated mean melt rates over the full KNS ice tongue (up to $1.3 \pm 0.6 \mathrm{~m} \mathrm{~d}^{-1}$ ) are in line with our previous 2013 mean melt rate estimate of $0.8 \pm$ $0.3 \mathrm{~m} \mathrm{~d}^{-1}$ (Moyer and others, 2017) while our maximum melt rate (just over $7 \mathrm{~m} \mathrm{~d}^{-1}$ ) compares well with modelled average KNS ice front estimates of 3-7 $\mathrm{m} \mathrm{d}^{-1}$ (Motyka and others, 2017). Our melt rates are also the same order of magnitude as those estimated under Greenland tidewater glacier floating termini between 2000 and 2010, which reach over $2.0 \mathrm{~m} \mathrm{~d}^{-1}$ in both central west (Jakobshavn and Rink) and east (Daugaard Jensen) Greenland (Enderlin and Howat, 2013).
Variations in SMRs depend on multiple factors, scaling with both ambient water temperature and plume velocity (e.g., Holland and Jenkins, 1999; Jenkins, 2011). Ambient winter and spring water temperatures measured at depths between 120 and $150 \mathrm{~m}$ (in which the deepest draft of the ice tongue sits) in Kangersuneq Fjord do not change substantially from 2012 to 2014 , averaging $\sim 1.5^{\circ} \mathrm{C}$ for all months during our study period, with the exception of March 2013, which averaged $2.0^{\circ} \mathrm{C}$ (Mortensen and others, 2013; Motyka and others, 2017). As such, it is unlikely that changes in ambient water temperature at depth ( 33\% increase from 2012 to 2013) are driving the temporal variations seen in our SMR estimates $(\sim 38 \%$ decrease in ice tongue averaged melt rate from 2012 to 2013).

\subsection{Subglacial discharge plumes}

The presence of subglacial plumes, resulting from surface and basally generated meltwaters, also influences SMRs. In the winter and early spring, subglacial discharge from surface meltwater is expected to be negligible. Plumes may however still be generated by subglacial discharge resulting from frictional melting beneath the grounded part of the glacier (Christoffersen and others, 2012). To assess the potential influence of basal frictional melting on driving winter and spring plumes, we estimated basal meltwater flux for the entire KNS catchment using a simplified equation for basal melt rate (Christoffersen and others, 2012), dependent upon ice velocity and density, basal drag and the latent heat of 

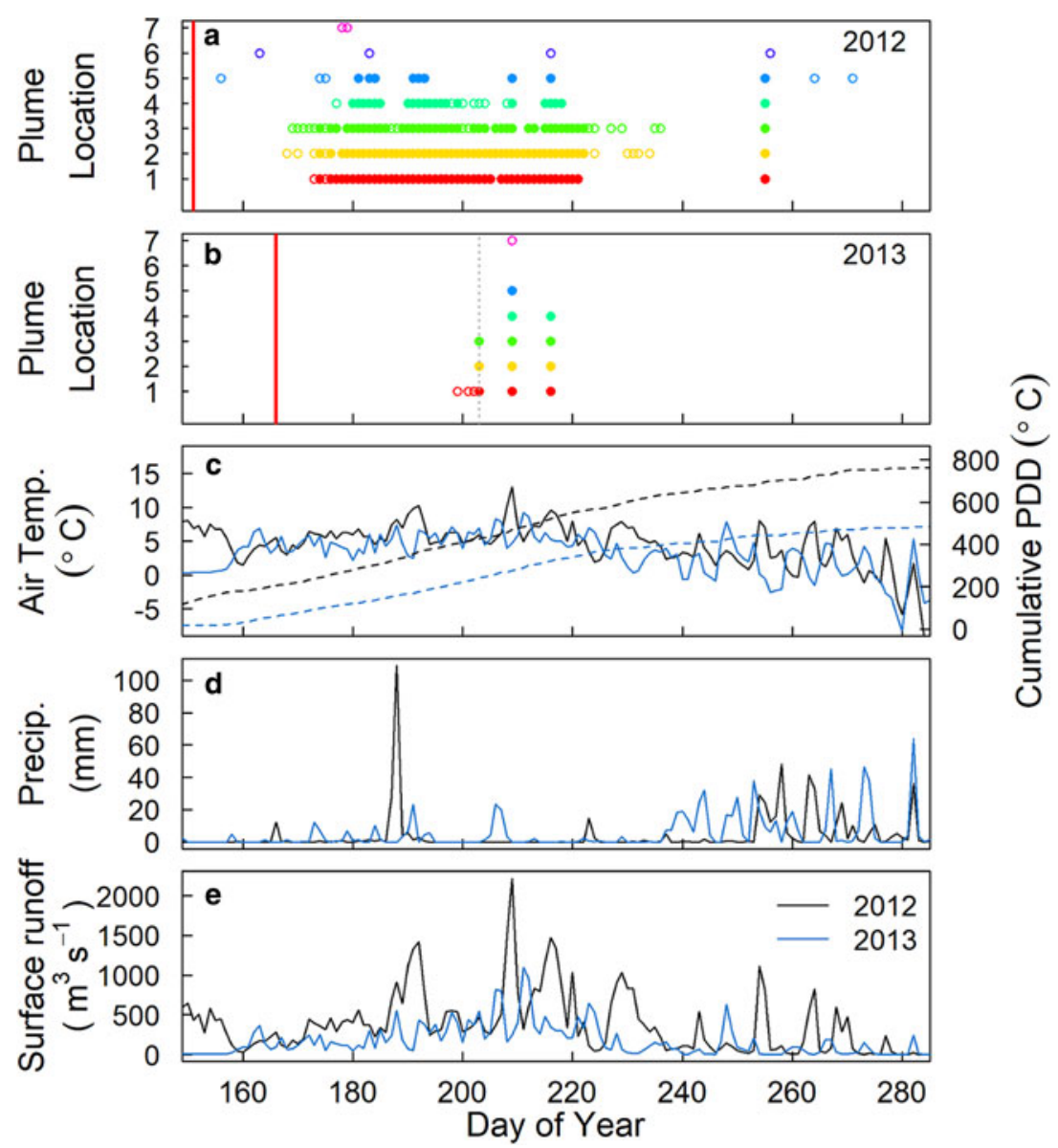

Fig. 4. (a, b) Time series of subglacial plume surface expression for (a) 2012 and (b) 2013 (see Fig. 2c for plume locations), where hollow circles indicate separate, individual plumes and filled circles indicate plumes seen as a single large coalesced plume on the fjord surface; the red vertical line indicates the date of ice tongue disintegration and the grey dashed vertical line indicates the date of the last time-lapse image; (c-e) Time series of (c) daily average air temperature (solid lines, left axis) and cumulative positive degree day (PDD) sum (dashed lines, right axis), (d) daily precipitation, and (e) catchment-wide surface runoff over KNS from degree-day modelling for 2012 (black lines) and 2013 (blue lines).

fusion (see Supplementary materials for equation and data sources). Estimated basal meltwater fluxes were 29.4, 28.9 and $29.1 \mathrm{~m}^{3} \mathrm{~s}^{-1}$ for 2012,2013 and 2014 , respectively. Frictional melting is likely therefore able to sustain active plumes through the winter and into early spring, augmenting SMRs. However, once the melt season begins, runoff from surface melting will dominate, sustaining larger plumes and promoting higher melt rates. This is likely the case in May 2012, when the melt season began early and where we estimate May runoff reaching $500 \mathrm{~m}^{3} \mathrm{~s}^{-1}$ (Fig. 4e) and melt rates exceeding $7 \mathrm{~m} \mathrm{~d}^{-1}$.

Subglacial plumes, sourced primarily from glacier surface meltwaters exiting at the grounding line, can be observed at the surface of the fjord near the KNS grounding line in latespring and summer each year, following ice tongue disintegration. Analysis of time-lapse imagery from 2012 shows that nearly all of the observed plumes on the fjord surface $(\sim 97 \%)$ occurred along the western half of the calving front (Figs 3a and $4 a$, plumes 1-5). We note, however, that due to the restricted view from the time-lapse camera, it is possible we are missing occurrences of surfacing plumes on the eastern side of the calving front. Nevertheless, the surface expression of plumes west of the calving front center for nearly all of the melt season suggests consistent delivery of meltwater, via a network of several subglacial channels, at corresponding locations along the glacier grounding line (e.g., Slater and others, 2017b). In instances where there is only one large plume visible on the fjord surface, it is impossible to tell which subglacial channels are 'active,' or if the channel network is unstable, particularly if one channel is dominant. Several channels could have persisted from the previous melt season, sustained by the release of frictional meltwater generated from basal sliding or from surface melt runoff due to an early on-set to the melt season, thereby promoting the high melt rates observed in May 2012 under the western side of the ice tongue (e.g., Fig. 3a).

The surface expression of plumes is infrequent in 2013 (Fig. 4b), likely due to the much lower catchment-wide surface runoff volume across the melt season (2.1 and 4.8 $\mathrm{km}^{3}$ for May to October 2013 and 2012, respectively, based on degree-day estimates), resulting in lower subglacial discharge at the grounding line and fewer plumes reaching the surface of the fjord (e.g., Slater and others, 2015; Carroll and others, 2016). In addition, the surface expression of plumes occurs much earlier in 2012 (day 156) than 2013 (day 199), likely due to the warmer air temperatures observed in 2012 (Fig. 4c) causing both an earlier break-up of the ice tongue and an earlier on-set of the melt season.

\subsection{Subglacial hydrology network}

The spatial pattern of our SMR estimates for 2013 changes between March and May, with higher melt rates under the eastern side of the ice tongue in mid-March, followed by 
higher melt rates under the western side of the ice tongue by the end of May (Fig. 3b, c), suggesting a change in the primary location of subglacial plumes exiting the glacier. In 2014, our melt rate estimates are again higher beneath the eastern side of the ice tongue, potentially indicating an oscillating subglacial hydrological network beneath KNS, with the main subglacial channels shifting between the western and eastern side of the ice tongue.

Results from our hydropotential analysis suggest that the location of the emerging subglacial runoff is sensitive to subtle changes in subglacial water pressure. Using a basal water pressure from 90 to $100 \%$ of the ice overburden pressure predicts a major subglacial channel on the far eastern side of the calving front, as well as two smaller channels on the western half of the calving front (Figs 3b, d, e and Figs S6b, c). This channel configuration is consistent with the higher melt rates on the eastern side of the fjord that we observe in March 2013 and May and June 2014. Reducing the basal water pressure to anywhere from 10 to $80 \%$ of ice overburden results in a significant change in inferred channel location, with a major subglacial channel now predicted on the western side of the calving front (Figs 3a, c and Figs $\mathrm{S} 6 \mathrm{~d}-\mathrm{f}$ ), closer to where we see most large plumes emerging at the fjord surface in 2012, and where we observe higher SMRs under the spring ice tongue. The predicted locations of subglacial runoff are therefore sensitive to changes in basal water pressure, suggesting that near-terminus subglacial channels are likely mobile and highly dynamic (e.g., Slater and others, 2017b).

\subsection{Calving and ice front shape changes}

Further analysis of the 2012 time-lapse imagery reveals that the majority of the calving events observed during the melt season $(\sim 91 \%)$ occur where we predominantly see subglacial plume surface expressions and where we estimated higher SMRs under the spring ice tongue. The occurrence of increased calving over areas of high submarine melting has been observed at tidewater glaciers in central west Greenland (e.g., Fried and others, 2015) and Alaska (e.g., Bartholomaus and others, 2013), where calving is driven by thermal undercutting of the ice front via submarine melting (e.g., O'Leary and Christoffersen, 2013). These areas of increased calving can create pronounced embayments along the calving front, often located above subglacial outlet channels (e.g., Chauché and others, 2014; Fried and others, 2015), and as we observe along the western half of the KNS ice front during the 2012 melt season (Fig. S7). As we have limited time-lapse imagery for 2013 and no imagery for 2014, we cannot determine whether the relationship between subglacial plume presence, submarine melting and calving holds true for other years at KNS. Ice velocities approaching the terminus are not significantly different across the width of the ice tongue in any given year, suggesting a similar ice flux delivery to the terminus across the calving front. We argue therefore that the presence of subglacial meltwater plumes has a large influence on localized calving, which must shift with time along the ice front, or else the terminus planform shape would change gradually to reflect the dominance of calving that we observe on the western side in 2012

\section{CONCLUSIONS}

Dynamic changes in tidewater glaciers have led to increases in ice discharge from the Greenland ice sheet over recent decades, yet the processes controlling these dynamic changes remain poorly understood, particularly the role of submarine melting. Here, using high-resolution DEMs and ice velocity, we estimate SMRs under the seasonal ice tongue of KNS in southwest Greenland from 2012 to 2014, revealing significant near-terminus spatial and temporal variations in spring melt rates. We estimate SMRs of up to $7.3 \pm 2.3 \mathrm{~m} \mathrm{~d}^{-1}$ under the western side of the ice tongue in May 2012, with the spatial pattern of melt rate corresponding to the locations of surface expressions of subglacial discharge plumes during the melt season of the same year. In addition, the greatest abundance of observed calving in 2012 occurs where we predominately see subglacial plumes. The spatial pattern of estimated SMR varies from 2012 to 2014, with areas of higher melt switching between the western and eastern side of the ice tongue. We attribute these changes to a switching of subglacial flow paths, a hypothesis supported by modelled subglacial flow routing, which shows that the main channel will emerge on either the eastern or western side of the fjord, dependent on subtle changes in the ratio between basal water pressure and ice overburden pressure. Our results provide a new empirically derived link (i.e., non-laboratory or modelled result) between the presence of subglacial discharge plumes, and thus subglacial outlet channel locations, and areas of higher submarine melting and calving at tidewater glacier termini, and can be used to improve our understanding of the coupling between tidewater glacier termini and the ocean.

\section{SUPPLEMENTARY MATERIAL}

The supplementary material for this article can be found at https://doi.org/10.1017/jog.2019.27

\section{ACKNOWLEDGEMENTS}

ANM is supported by a University of Edinburgh Principal's Career Development PhD Scholarship. We acknowledge NERC grants NE/K015249/1 (to PWN) and NE/K014609/1 (to AJS) and DLR projects XTI_GLAC0296 and LAN1534 (to NG). Time-lapse imagery was acquired under NSF grant PLR0909552 (to MT and MF). PROMICE and DMI data are available at http://www.promice.dk and http://www.dmi.dk, respectively. ArcticDEM was created from DigitalGlobe Inc. imagery, funded under NSF awards 1043681, 1559691, and 1542736.

\section{REFERENCES}

Ahlstrom AP and the PROMICE Project Team (2008) A new programme for monitoring the mass loss of the Greenland ice sheet. Geol. Surv. Denmark Greenl. Bull., 15, 61-64

Andrews LC and 7 others (2014) Direct observations of evolving subglacial drainage beneath the Greenland ice sheet. Nature, 514, 80-83 (doi: 10.1038/nature13796)

Banwell AF, Willis IC and Arnold NS (2013) Modeling subglacial water routing at Paakitsoq, W Greenland. J. of Geophys. Res. Earth Surf., 118(3), 1282-1295 (doi: 10.1002/jgrf.20093)

Bartholomaus TC, Larsen CF and O'Neel S (2013) Does calving matter? Evidence for significant submarine melt. Earth Planet. Sci. Lett., 380, 21-30 (doi: 10.1016/j.epsl.2013.08.14)

Cappelen J ed. (2016), Greenland - DMI Historical Climate Data Collection 1784-2016. DMI Report 17-04, Copenhagen, www.dmi.dk/laer-om/generelt/dmi-publikationer/2013

Carroll D and 5 others (2015) Modeling turbulent subglacial meltwater plumes: implications for fjord-scale buoyancy-driven circulation. J. Phys. Oceanogr., 45, 2169-2185 (doi: 10.1175/ JPO-D-15-0033.1) 
Carroll D and 11 others (2016) The impact of glacier geometry on meltwater plume structure and submarine melt in Greenland fjords. Geophys. Res. Lett., 43, 9739-9748 (doi: 10.1002/ 2016GL070170)

Cenedese C and Gatto VM (2016) Impact of a localized source of subglacial discharge on the heat flux and submarine melting of a tidewater glacier: a laboratory study. J. Phys. Oceanogr., 46, 3155-3163 (doi: 10.1175/JPO-D-16-0123.1)

Chauché $\mathrm{N}$ and 8 others (2014) Ice-ocean interaction and calving front morphology at two west Greenland tidewater outlet glaciers. Cryosphere, 8, 1457-1468 (doi: 10.5194/tc-8-14572014)

Christoffersen P, O'Leary M, van Angelen JH and van den Broeke M (2012) Partitioning effects from ocean and atmosphere on the calving stability of Kangerdlugssuaq Glacier, East Greenland. Ann. Glaciol., 53(60), 249-256 (doi: 10.3189/2012AoG60A087)

Dehecq A and 5 others (2016) Elevation changes inferred from TanDEM-X data over the Mont-Blanc area: impact of the Xband interferometric bias. IEEE J-STARS, 9, 3870-3882 (doi: 10.1109/JSTARS.2016.2581482)

Enderlin EM and Howat IM (2013) Submarine melt rate estimates for floating termini of Greenland outlet glaciers (2000-2010). J. Glaciol., 59, 67-75 (doi: 10.3189/2013JoG12J049)

Fountain AG and Walder JS (1998) Water flow through temperate glaciers. Rev. of Geophys., 36(3), 299-328 (doi: 10.1029/ 97RG03579)

Fried MJ and 8 others (2015) Distributed subglacial discharge drives significant submarine melt at a Greenlandic tidewater glacier. Geophys. Res. Lett., 42, 9328-9336 (doi: 10.1002/2015GL065806)

Hock R (2003) Temperature index melt modelling in mountain areas. J. Hydro., 282, 104-115 (doi: 10.1016/S0022-1694(03)00257-9)

Holland DM and Jenkins A (1999) Modeling thermodynamic iceocean interactions at the base of an Ice shelf. J. Phys. Oceanogr., 29, 1787-1800.

Holland DM, Thomas $\mathrm{RH}$, de Young $\mathrm{B}$, Ribergaard $\mathrm{MH}$ and Lyberth B (2008) Acceleration of Jakobshavn Isbrae triggered by warm subsurface ocean waters. Nat. Geosci., 1(10), 659664 (doi: 10.1038/ngeo316)

Jenkins A (2011) Convection-driven melting near the grounding lines of ice shelves and tidewater glaciers, J. Phys. Oceanogr., 41, 2279-2294 (doi: 10.1175/JPO-D-11-03.1)

Krabill WB (2016) Ice bridge ATM L1B elevation and return strength. NASA DAAC at the National Snow and Ice Data Center, Boulder, Colorado, USA (doi: 10.5067/19SIM5TXKPGT)

Langen PL and 13 others (2015) Quantifying energy and mass fluxes controlling Godthåbsfjord freshwater input in a $5-\mathrm{km}$ simulation (1991-2012). J. Climate, 28, 3694-3713 (doi: 10.1175/JCLI-D14-00271.1)

Langen PL, Fausto RS, Vandecrux B, Mottram RH and Box JE (2017) Liquid water flow and retention on the Greenland ice sheet in the regional climate model HIRHAM5: local and LargeScale impacts. Front. Earth Sci., 4, 110 (doi: 10.3389/feart.2016.00110)

Luckman A and 5 others (2015) Calving rates at tidewater glaciers vary strongly with ocean temperature. Nat. Commun., 6, 8566 (doi: 10.1038/ncomms9566)

Meierbachtol T, Harper J and Humphrey N (2013) Basal drainage system response to increasing surface melt on the Greenland ice sheet. Science, 341(6147), 777-779 (doi: 10.1126/ science.123590)

Morin P and 7 others (2016) ArcticDEM; a publically available, high resolution elevation model of the Arctic. EGU Gen. Assem. Conf. Abstr., 18, 8396

Morlighem M and 31 others (2017) Bedmachine v3: complete bed topography and ocean bathymetry mapping of Greenland from multi-beam echo sounding combined with mass conservation. Geophys. Res. Lett., 44, 11051-11061 (doi: 10.1002/ 2017GL074954)

Mortensen J and 6 others (2013) On the seasonal freshwater stratification in the proximity of fast-flowing tidewater outlet glaciers in a sub-Arctic sill fjord. J. of Geophys. Res. Oceans, 118, 13821395 (doi: 10.1002/jgrc.20134)

Motyka RJ, Hunter L, Echelmeyer K and Connor C (2003) Submarine melting at the terminus of a temperate tidewater glacier, Le Conte Glacier, Alaska. Ann. Glaciol., 36, 57-65

Motyka RJ, Dryer WP, Amundson J, Truffer M and Fahnestock M (2013) Rapid submarine melting driven by subglacial discharge, LeConte Glacier, Alaska. Geophys. Res. Lett., 40, 5153-5158 (doi: 10.1002/grl.51011)

Motyka RJ and 11 others (2017) Asynchronous behavior of outlet glaciers feeding Godthåbsfjord (Nuup Kangerlua) and the triggering of Narsap Sermia's retreat in SW Greenland. J. Glaciol., 63, 288-308 (doi: 10.1017/jog.2016.138)

Moyer AN, Nienow PW, Gourmelen N, Sole AJ and Slater DA (2017) Estimating spring terminus submarine melt rates at a Greenlandic tidewater glacier using satellite imagery. Front. Earth Sci. Cryosphere, 5, 107 (doi: 10.3389/feart.2017.00107)

O'Leary M and Christoffersen P (2013) Calving on tidewater glaciers amplified by submarine frontal melting. Cryosphere, 7(1), 119128 (doi: 10.5194/tc-7-119-2013)

Paul F and 24 others (2015) The glacier climate change initiative: methods for creating glacier area, elevation change and velocity products. Remote Sens. Environ., 162, 408-426 (doi: 10.1016/ jrse.2013.07.043)

Pfeffer WT and Meier MF (1991) Retention of Greenland runoff by refreezing: implications for projected future Sea level change. J. Geophys. Res. Oceans, 96, 22117-22124 (doi: 10.1029/ 91JC02502)

Rizzoli P, Bräutigam B, Kraus T, Martone M and Krieger G (2012) Relative height error analysis of TanDEM-X elevation data. ISPRS J. Photogramm., 73, 30-38 (doi: 10.1016/j.isprsjprs.2012.06.004)

Rosenau R, Scheinert M and Dietrich R (2015) A processing system to monitor Greenland outlet glacier velocity variations at decadal and seasonal timescales utilizing the landsat imagery. Remote Sens. Environ., 169, 1-19 (doi: 10.1016/j.rse.2015.07.012)

Schwanghart W and Scherler D (2014) Short communication: topoToolBox 2 - MATLAB-based software for topographic analysis and modelling in earth surface sciences. Earth Surf. Dynam., 2, 1-7 (doi: 10.5194/esurf-2-1-2014)

Shreve RL (1972) Movement of water in glaciers. J. Glaciol., 11(62), 205-214 (doi: 10.3189/S002214300002219X)

Slater DA, Nienow PW, Cowton TR, Goldberg DN and Sole AJ (2015) Effect of near-terminus subglacial hydrology on tidewater glacier submarine melt rates. Geophys. Res. Lett., 4, 2861-2868 (doi: 10.1002/2014GL062494)

Slater DA, Nienow PW, Goldberg DN, Cowton TR and Sole AJ (2017a) A model for tidewater glacier undercutting by submarine melting, Geophys. Res. Lett., 44, 2360-2368 (doi: 10.1002/ 2016GL072374)

Slater DA and 6 others (2017b) Spatially distributed runoff at the grounding line of a large Greenlandic tidewater glacier inferred from plume modelling. J. Glaciol., 63, 309-323 (doi: 10.1017/ jog.2016.139).

Straneo F and Heimbach P (2013) North Atlantic warming and the retreat of Greenland's outlet glaciers. Nature, 504, 36-43 (doi: 10.1038/nature12854)

van den Broeke MR and 7 others (2016) On the recent contribution of the Greenland ice sheet to sea level change. Cryosphere, 10 (5), 1933-1946 (doi: 10.5194/tc-10-1933-2016) 